\title{
Infestation of Rhynchopsyllus pulex (Siphonaptera: Tungidae) on Molossus molossus (Chiroptera) in Southestern Brazil
}

\author{
Carlos Esbérard
}

\begin{abstract}
Projeto Morcegos Urbanos, Fundação Riozoo, Quinta da Boa Vista s/nº , 20940-040 Rio de Janeiro, RJ, Brasil
\end{abstract}
The infestation of Rhynchopsyllus pulex on the bat Molossus molossus was observed using mistnets opened between constructions in the Primatological Center, in Guapimirim, State of Rio de Janeiro, Brazil.

Key words : Rhynchopsyllus pulex - Siphonaptera - Molossus molossus - Brazil

Rhynchopsyllus pulex Haller, 1880 is an obligate parasite of bats, with the females attached to bats, and males being unknown for long. After another species, $R$. megastigmata have been considered conspecific with $R$. pulex by Méndez (1977); males are now known. According to Hastriter and Méndez (2000), females have been captured frequently on chiropteran hosts while males have been collected only from bat guano associated with species of Molossus in Colombia and Panamá. Twelve species of bats have already been reported with this interaction: Phyllostomus hastatus (Family Phyllostomidae), Myotis nigricans, Eptesicus brasiliensis, Histiotus velatus (Family Vespertilionidae), Tadarida brasiliensis, M. molossus, M. obscurus, M. major, M. ater, Eumops perotis and Nyctinomops macrotis (Family Molossidae). This same infestation has been reported on rodents and birds, although, probably, representing accidental reports (Tipton \& Machado-Allison 1972). This flea occurs in the Neotropical Region, with only one species known from Brazil, at Pernambuco, Bahia, Minas Gerais, Rio de Janeiro, São Paulo and Paraná(Linardi \& Guimarães 2000). The ingurgitated female is visible to the naked eye.

From 1998 to 1999, during a bat sampling in the Centro de Primatologia do Rio de Janeiro, Guapimirim, State of Rio de Janeiro, southeastern Brazil, this flea was observed infesting M. molossus. Bats were captured in this area using three mist nets opened between the houses during seven nights. All the netted bats are marked with neck-

E-mail: morcegos@pcrj.rj.gov.br. Received 27 December 2000 Accepted 27 June 2001 laces made by tier-ups with colored cylinders for individual identification (Esbérard \& Daemon 1999) and released after measurement. Ectoparasites were not removed.

A large colony of $M$. nigricans and $M$. molossus was identified, into the roof of one house. In the roof of another house, $M$. nigricans, $M$. ater, $M$. molossus and P. hastatus were captured. Using mist nets during seven nights $(252 \mathrm{~h} /$ nets $) 356 \mathrm{M}$. molossus were netted. The prevalences of infestation from April 1998 to June 1999 are presented in the Table. In the second roost the use of mist net was not possible due to the height of the roof and the sampling was restricted to manual capture, including youngs of $M$. ater.

Of the total of $M$. molossus netted, $8.14 \%$ had R. pulex (Fig. 1). Fleas attached preferentially on the bat's head (Fig. 2), with a single parasite observed on right forearm. A number of 65 fleas was obtained from 29 adult bats (14 males and 15 females). In male, 22 parasites were counted, with variance from 1 to 6 fleas and average of $1.57( \pm 1.41)$. None bat captured in the second roof has any flea. Forty-three fleas were observed on female bats, with variance from 1 to 9 fleas and average of $2.87( \pm 3.27)$. Higher parasitic load could be expected in females, because they appeared to be more sessile than males, but it was not founded $(\mathrm{t}=2.0127, \mathrm{p}=0.0637)$. Males M. molossus usually move to another shelter after mating, while the females remain in maternities for birthing. The males, if remained in the same shelter, do not have contact with the females (Nowak 1995). Infestation of R. pullex on other species of bats was not observed, even on bats cohabitating with the parasitized $M$. molossus, totalizing $142 \mathrm{M}$. nigricans, $5 \mathrm{E}$. brasiliensis, $4 P$. hastatus and $25 \mathrm{M}$. ater. 


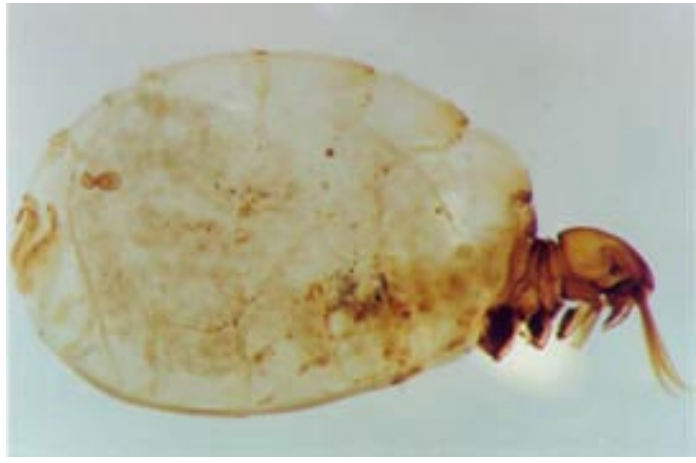

Fig. 1: female Rhynchopsyllus pulex taken from Molossus molossus

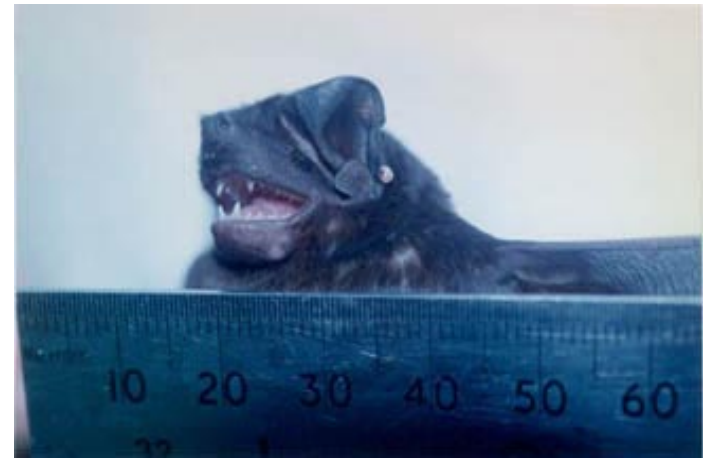

Fig 2: Rhynchopsyllus pulex on Molossus molossus

\section{TABLE}

Infestation of Molossus molossus by Rhynchopsyllus pulex

\begin{tabular}{lcccccccc}
\hline & \multicolumn{8}{c}{ Month/year of sampling } \\
\cline { 2 - 9 } & $4 / 1998$ & $6 / 1998$ & $7 / 1998$ & $8 / 1998$ & $9 / 1998$ & $11 / 1998$ & $06 / 1999$ & Total \\
\hline Captured & 89 & 121 & 62 & 31 & 34 & 10 & 9 & 356 \\
$\%$ & 25 & 33.9 & 17.4 & 8.7 & 9.5 & 2.8 & 2.5 & 100 \\
Infested & 3 & 3 & 6 & 1 & 33 & 7 & 6 & 29 \\
$\%$ & 3.4 & 2.5 & 9.7 & 3.2 & 8.8 & 70 & 66.6 & 8.1 \\
\hline
\end{tabular}

\section{ACKNOWLEDGEMENTS}

To Dr Charles Esbérard for the English version of the manuscript, Rafael V Monteiro, and two anonymous reviewers for the criticism and help with the English version. To Dr Alcides Pissinati, for permission to collect in the Centro de Primatologia do Rio de Janeiro, to Adriana Pereira Cifali for the help in the field work and for preparing the slide and to Dr Cristina Valéria, from Fiocruz, for the photography work.

\section{REFERENCES}

Esbérard CE, Daemon C 1999. Método para marcação de morcegos. Chirop Neotrop 5: 116-117.

Hastriter MW, Méndez E 2000. A review of the flea genera Hectopsylla Frauenfeld and Rhynchopsyllus Haller (Siphonaptera: Pulicidae). Proc Entomol Soc Wash 103: 613-624.

Linardi PM, Guimarães LR 2000. Sifonápteros do Brasil, Museu de Zoologia USP, Fapesp, São Paulo, 291 pp.

Méndez E 1977. Mammalian-siphonapteran associations, the environment and biogegraphy of mammals of Southwestern Colombia. Quaest Entomol 13: 91182.

Nowak RM 1995. Walker's Mammals of the World, 4th ed., The John Hopkins University Press, Baltimore, 1629 pp.

Tipton VJ, Machado-Allison CE 1972. Fleas of Venezuela. Brigham Young Univer Sci Bul 17: 1-115. 